\title{
Accumulation of Lipid in Muscular Arteries of Short-term Diabetic Rats
}

\author{
An Electron Microscope Study
}

A. Reinilä, H. K. Åkerblom, and R. O. Scow

Departments of Pathology and Paediatrics, University of Oulu, Oulu, Finland, and Section on Endocrinology, Laboratory of Nutrition and Endocrinology, National Institute of Arthritis, Metabolism and Digestive Diseases, Bethesda, Maryland, USA

Summary. Lipid accumulation in muscular (pulmonary, coronary and tibial) arteries and elastic (aorta and pulmonary) arteries of streptozotocin diabetic $(65 \mathrm{mg} / \mathrm{kg})$ rats was studied with an electron microscope. Arterial tissue specimens taken 4 days after the induction of diabetes showed lipid deposits in smooth muscle cells in the muscular arteries of 9 out of 24 diabetic rats, but in none of the 17 control rats. Histochemically the lipid was identified as triacylglycerol. Lipid accumulation was not seen in the elastic arteries of either diabetic or control rats. The diabetic animals with lipid deposits had slightly but significantly higher plasma glucose concentrations $(\mathrm{p}$ $<0.02)$, higher non-esterified fatty acids levels ( $p<$ $0.01)$, and lower concentrations of plasma insulin ( $\mathrm{p}$ $<0.02$ ) than those without arterial deposits. The amount of lipid deposited in the arteries was closely related to the plasma non-esterified fatty acid level, which was in the ranges $0.8-1.1 \mathrm{mmol} / 1$ in diabetic rats without deposits, and $1.1-2.4 \mathrm{mmol} / 1$ in those with deposits. The findings suggest that lipid accumulation in smooth muscle cells of muscular arteries during acute diabetes could result from the high plasma non-esterified fatty acid concentrations.

Key words: Diabetes, streptozotocin, coronary artery, muscular pulmonary artery, tibial artery, aorta, main pulmonary artery, elastic arteries, plasma non-esterified fatty acid (NEFA).

It is well known that diabetes is a high risk factor in arteriosclerosis [1, 2]. Although it is generally thought that elevated levels of circulating lipids might be involved, the mechanism of development of arteriosclerosis in diabetes is still unknown.
Our previous light microscope histochemical studies showed a rapid accumulation of triacylglycerol in branches of the pulmonary artery in diabetic rats, developing within three days of the injection of streptozotocin [3] and disappearing rapidly with insulin therapy [4].

The present study was initiated: 1) to determine the ultrastructural aspects of lipid deposits in pulmonary arteries during short-term experimental diabetes; 2) to search for possible lipid deposits in other arteries, both muscular and elastic; 3) to establish whether there was any relation between lipid deposition and circulating levels of insulin, glucose or lipids.

\section{Material and Methods}

\section{Animals and Induction of Diabetes}

Male Sprague-Dawley rats weighing $300-350 \mathrm{~g}$ were used. The series consisted of 24 diabetic and 17 normal control rats. The animals were fed a normal chow ad libitum (carbohydrate $53 \%$, protein $21 \%$, fat $4.5 \%$, fibre $3 \%$ and required vitamins and minerals, obtained from Hankkija, Turku, Finland).

Diabetes was induced under pentobarbitone anaesthesia by an intracardiac [5] injection of streptozotocin (Upjohn, lot $1614 \mathrm{E}$, MCM 3 ), $65 \mathrm{mg} / \mathrm{kg}$ of body weight, as a freshly prepared $3 \%(\mathrm{w} / \mathrm{v})$ solution in $0.1 \mathrm{~mol} / 1$ citrate buffer $(\mathrm{pH} 4.5)$. No insulin treatment was given. The control rats received an equal volume of buffer. The diabetic rats were killed four days after the injection. All animals were weighed at the start and finish of the experiment, and checked for glycosuria (Clinitest, Ames, Elkhart, Indiana) and ketonuria (Ketostix, Ames).

\section{Blood Sampling and Analysis}

Blood was drawn from the retro-orbital venous plexus of the nonfasting rats through a capillary tube while the rat was under pentobarbitone anaesthesia, and collected in ice-cold EDTA tubes (final concentration of EDTA, $21.7 \mu \mathrm{mol} / \mathrm{l}$ ) [6]. The animals were then killed by decapitation immediately. 
Table 1. Plasma glucose, insulin, NEFA, triacylglycerol and total cholesterol concentrations in normal and diabetic rats. (Mean \pm SEM except for plasma NEFA values, which are given as median and range because of skew distribution)

\begin{tabular}{llllllll}
\hline Group & $\begin{array}{l}\text { Number } \\
\text { of } \\
\text { animals }\end{array}$ & Glasma concentration & & & \\
\cline { 3 - 7 } & & $\mathrm{mg} / 100 \mathrm{ml}$ & $\mathrm{mU} / \mathrm{l}$ & $\mathrm{mmol} / \mathrm{l}$ & $\begin{array}{c}\text { Triacyl- } \\
\text { glycerol } \\
\mathrm{mg} / \mathbf{1 0 0} \mathrm{ml}\end{array}$ & $\begin{array}{c}\text { Total cho } \\
\text { lesterol } \\
\mathrm{mg} / 100 \mathrm{ml}\end{array}$ \\
\hline $\begin{array}{l}\text { Normal control } \\
\begin{array}{l}\text { Diabetic without } \\
\text { arterial lipid }\end{array}\end{array}$ & 17 & $101 \pm 3$ & $28.5 \pm 2.3$ & $0.5(0.3-0.6)$ & $161 \pm$ & 7 & $65 \pm 3$ \\
$\begin{array}{c}\text { Diabetic with } \\
\text { arterial lipid }\end{array}$ & 9 & $305 \pm 8^{\mathrm{a}}$ & $7.5 \pm 1.0^{\mathrm{b}}$ & $0.9^{\mathrm{c}}(0.8-1.1)$ & $988 \pm 128$ & $129 \pm 9$ \\
\hline
\end{tabular}

Blood was drawn from diabetic rats 4 days after injection with streptozotocin, $65 \mathrm{mg} / \mathrm{kg}$

All animals had access to food and water until blood sampling under anaesthesia

${ }^{\mathrm{a}, \mathrm{b}} \mathrm{p}<0.02$

${ }^{c} \mathrm{p}<0.01$

Blood samples were cooled to $4{ }^{\circ} \mathrm{C}$, and the plasma separated by centrifugation within $2 \mathrm{~h}$. Plasma specimens were stored at $-20^{\circ} \mathrm{C}$ until analysed for glucose $[7,8]$, non-esterified fatty acids (NEFA) [9], triacylglycerol [10] and total cholesterol [11]. Plasma insulin was measured by radioimmunoassay (Phadebas Insulin Test, Pharmacia Diagnostics) with a standard of lyophilized porcine insulin, calibrated against the WHO insulin standard (WHO International Laboratory for Biological Standards). The detection limit of the assay was $3.0 \mathrm{mU} / 1$. There was full cross-reactivity between porcine and rat insulins. All measurements of plasma constituents were made in duplicate.

\section{Preparation of Tissue Specimens for Morphological Study}

The pulmonary artery at $5 \mathrm{~mm}$ distal to hilus, the anterior tibial artery, and the proximal coronary artery are muscular arteries in the rat, having a thick media rich in smooth muscle cells. The aorta and the main pulmonary artery are elastic arteries consisting largely of elastic tissue.

Segments $2 \mathrm{~mm}$ long were taken from the following arteries immediately after decapitation: distal tibial, proximal part of left descending coronary, and pulmonary artery $5 \mathrm{~mm}$ distal to the hilus. Additional segments were taken from the ascending arch of the aorta and the main pulmonary artery. Segments were divided into strata from which eight pieces, $1 \mathrm{~mm} \times 1 \mathrm{~mm}$, were picked by random sampling [12], and placed in individual vials, fixed in $3 \%$

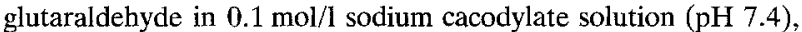
and washed in $0.1 \mathrm{~mol} / 1$ sodium cacodylate $(\mathrm{pH} 7.4)$. The tissue specimens were then cut into smaller pieces $(0.5 \mathrm{~mm} \times 0.5 \mathrm{~mm})$, and postfixed in $2 \%(\mathrm{w} / \mathrm{v}) \mathrm{OsO}_{4}$ in $0.1 \mathrm{~mol} / 1$ cacodylate solution (pH 7.4). All steps were carried out at $<4{ }^{\circ} \mathrm{C}$. Tissue specimens were dehydrated rapidly in graded acetone as described previously [13]. Eight pieces were then taken from each vial [12], and infiltrated with Epon [13]. Two sections of thickness $1 \mu \mathrm{m}$ were cut from each block using a LKB Ultratome III and glass knives, and stained with toluidine blue for light microscopy. Two thin sections were also cut from each block, stained with uranyl acetate and lead citrate [14] and examined in a JEM $100 \mathrm{~B}$ electron microscope (Japan Electron Optics Laboratory, Japan).

Sixteen thin sections of each artery were thus examined in the electron microscope to determine the distribution and amount of lipid deposits in the arterial wall. The sections were primarily examined by one investigator and re-evaluated by one co-worker.
The electron microscopic examination was performed without any knowledge whether an animal was diabetic or non-diabetic. The criterion for lipid was electron-opacity of oval or spherical structures, some of which were lamellar [13]. The amount of lipid in the arterial wall was graded from 0 to IV (very abundant). Special effort was made to distinguish accurately between grades 0 (no lipid) and I (slight lipid deposition).

Every section contained all the layers of the vessel wall. Smooth muscle cells were identified by myofilaments occurring in poorly defined bundles. Pinocytic vesicles were associated with the sarcolemma which was coated by basal membrane [15]. Foam cells were interpreted as smooth muscle cells, because some myofilaments were found in their cytoplasm.

Specimens were also taken from each artery for light microscope histochemical studies. These specimens were frozen with liquid $\mathrm{N}_{2}$ and stored at $-70^{\circ} \mathrm{C}$ until analysed for triacylglycerol [16], cholesterol [17] and phospholipids [18]. The histochemical methods are specific [16-18].

\section{Statistical Analysis}

The results on plasma glucose, insulin, triacylglycerol and total cholesterol are given as mean \pm SEM, and those on plasma NEFA as median and range because of a skew distribution. The differences between diabetic rats with and without arterial lipid was tested for plasma substances by Student's t test, except for plasma NEFA when the Mann-Whitney $U$ test was used. The coefficient of variation of our NEFA assay was $<2 \%$.

\section{Results}

\section{Severity of Diabetes}

The rats injected with streptozotocin lost $10-19 \%$ body weight and developed $3-5 \%$ glucosuria (Clinitest) and moderate $(++)$ to severe $(+++)$ ketonuria (Ketostix) in 4 days. They also had high plasma concentrations of glucose, NEFA, triacylglycerol and total cholesterol, and a low plasma concentration of insulin, confirming that they were severely diabetic at 4 days (Table 1 ). 
Table 2. Relationship between plasma NEFA concentration and amount of lipid in muscular arteries of rats

\begin{tabular}{|c|c|c|c|c|c|}
\hline \multirow[t]{2}{*}{ Group (n) } & \multirow{2}{*}{$\begin{array}{l}\text { Rat } \\
\text { no. }\end{array}$} & \multirow{2}{*}{$\begin{array}{l}\text { Plasma } \\
\text { NEFA } \\
\text { mmol/ }\end{array}$} & \multicolumn{3}{|c|}{ Amount of lipid in muscular arteries ${ }^{\mathrm{a}}$} \\
\hline & & & Pulmonary & Coronary & Tibial \\
\hline Normal [17] & - & $0.3-0.6$ & 0 & 0 & 0 \\
\hline $\begin{array}{l}\text { Diabetic without } \\
\text { arterial lipid [15] }\end{array}$ & - & $0.8-1.1$ & 0 & 0 & 0 \\
\hline $\begin{array}{l}\text { Diabetic with } \\
\text { arterial lipid [9] }\end{array}$ & $\begin{array}{l}1 \\
2 \\
3 \\
4 \\
5 \\
6 \\
7 \\
8\end{array}$ & $\begin{array}{l}1.1-2.4 \\
1.1 \\
1.1 \\
1.2 \\
1.3 \\
1.3 \\
1.5 \\
1.6 \\
2.0\end{array}$ & $\begin{array}{l}\text { II } \\
\text { II } \\
\text { II } \\
\text { III } \\
\text { II } \\
\text { III } \\
\text { III } \\
\text { IV }\end{array}$ & $\begin{array}{l}\text { I } \\
\text { I } \\
\text { I } \\
\text { II } \\
\text { II } \\
\text { II } \\
\text { II } \\
\text { II }\end{array}$ & $\begin{array}{l}\text { I } \\
\text { I } \\
\text { II } \\
\text { II } \\
\text { II } \\
\text { II } \\
\text { II } \\
\text { III }\end{array}$ \\
\hline
\end{tabular}

a Amount of lipid graded from 0 to IV (very abundant). NEFA concentrations are given as range for each group

\section{Accumulation of Lipid in the Muscular Arteries}

Spherical or oval structures, from $0.04 \mu \mathrm{m}$ to $0.19 \mu \mathrm{m}$ in size were found in the muscular pulmonary, tibial and coronary arteries of 9 out of 24 diabetic rats, but in none of the normal control rats (Table 2). The lipid was located in medial smooth muscle cells, especially those in the inner media (Fig. 1). No lipid was seen in the endothelium, subendothelial space, or extracellular space of the media. Lipid was most abundant in the muscular pulmonary artery (Table 2). Lipid deposits were often seen near mitochondria and the endoplasmic reticulum (Figs. 1 and 2). Transformation of smooth muscle cells into foam cells (Fig. 3), with massive accumulation of lipid in the cells, was found in the muscular pulmonary artery of one diabetic rat (Table 2, rat 9).

Light microscope histochemical studies demonstrated that the lipid deposits in the smooth muscle cells of the muscular arteries were triacylglycerol (Fig. 4). The histochemical reaction for triacylglycerol was negative in the muscular arteries of both diabetic rats without electron microscopically detectable lipid deposits and normal control rats. The histochemical reactions for lipid were also negative in the elastic arteries of all groups of rats. Neither cholesterol nor phospholipids were found histochemically in any arteries of the diabetic or control rats.

\section{Relationship between Plasma NEFA Concentration and Amount of Lipid Deposited in Muscular Arteries}

A comparison of the plasma concentrations of glucose, insulin and various lipids in the diabetic rats with and without arterial lipid deposits is given in
Table 1. The primary differences between the two groups were that plasma NEFA concentrations were higher and insulin concentrations slightly lower in the diabetic rats with arterial deposits. The data presented in Table 2 show a relationship between the plasma NEFA concentration and the amount of lipid deposited in the arteries. No correlation was found between plasma NEFA and triacylglycerol concentrations in the diabetic rats with or without arterial lipid deposits.

\section{Discussion}

Our findings demonstrate a marked effect of acute diabetes on lipid metabolism in muscular arteries, resulting in an accumulation of triacylglycerol in medial smooth muscle cells. The deposits were often associated with the smooth endoplasmic reticulum (SER) found in the cells principally in tubular and vesicular forms [19]. The most prominent role for the SER is in the synthesis of lipids, for example triacylglycerol from glycerol and NEFA [19]. The uptake of NEFA by cells has been reported to be an energy independent process, which functions only to maintain an equilibrium between the plasma and cellular pools of NEFA [20]. On the other hand, the excess of long chain fatty acids may act as an uncoupling agent in the cell causing mitochondria to respire but not synthesize adenosine triphosphate (ATP) [21]. The positive relationship between the plasma NEFA concentration and the amount of lipid deposited in the muscular arteries (Table 2) suggests that lipid deposition could result from an increased uptake and esterification of plasma NEFA derived from adipose 

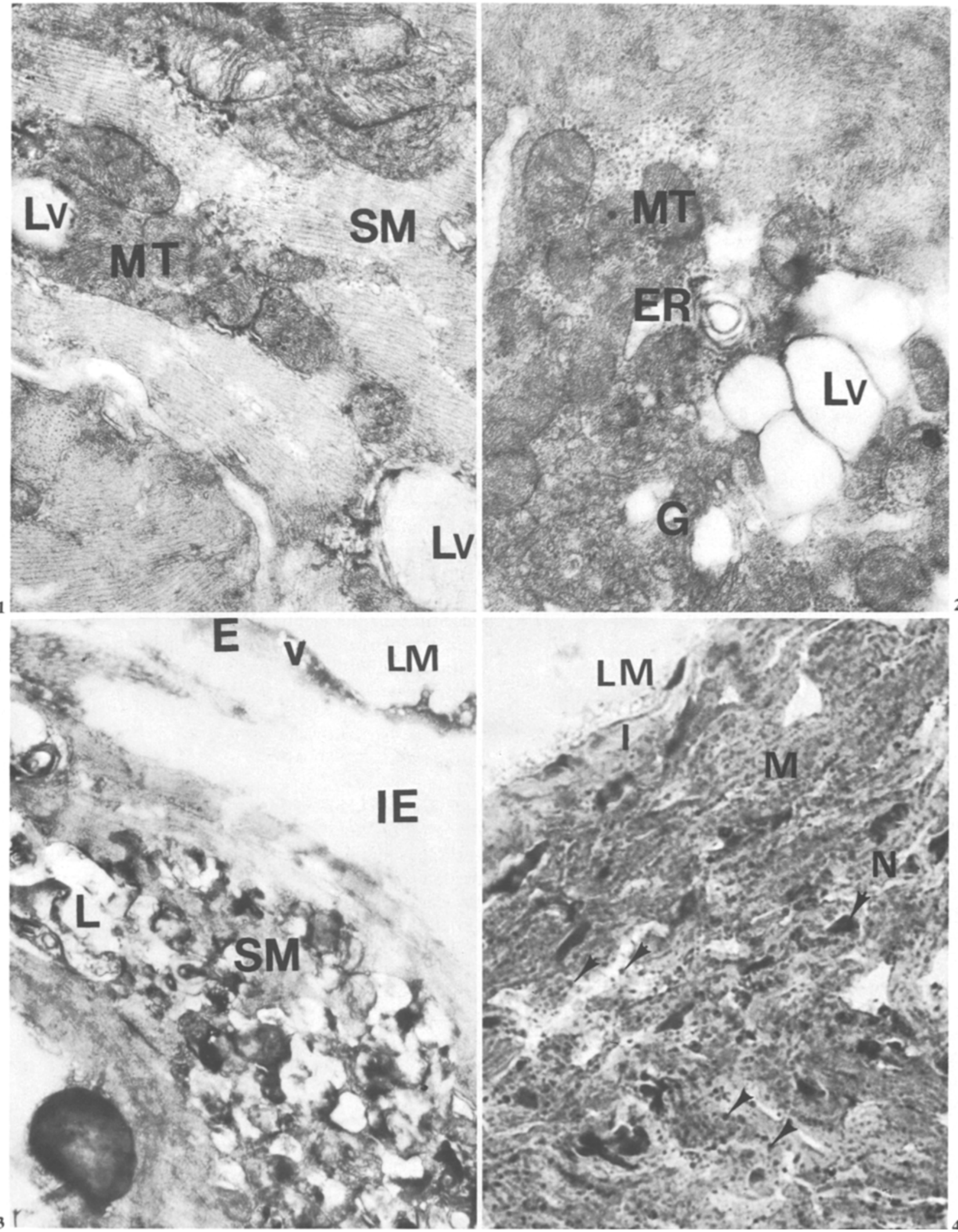
tissue during insulin deficiency [22]. There may also be decreased utilization of NEFA by mitochondria [21].

Most NEFA in plasma is bound to albumin [23, $24,25]$. The molar ratio of NEFA to albumin in Plasma seldom exceeds 2 under normal conditions, but it can be 3.5 in severe diabetes $[23,26,27]$. It has been shown that the uptake of NEFA by perfused organs [28] and incubated cells [27, 29] is a function of the molar ratio NEFA to albumin in the medium, and that the uptake by incubated cells is greatly enhanced, sometimes producing injurious effects, when the ratio exceeds $3[27,29]$. In the present study, assuming that the plasma albumin concentration was $0.48 \mathrm{mmol} / 1(3.2 \mathrm{~g} / 100 \mathrm{ml})$ [30], the molar ratio of NEFA to albumin was in the range $0.7-1.2$ in the normal rats, $1.6-2.4$ in the diabetic rats without arterial lipid deposits, and 2.3-5.1 in the rats with arterial deposits.

The elevation of plasma NEFA concentrations is a characteristic feature of insulin deficiency [22], being proportional in degree to the severity of diabetes [31]. Thus the difference in plasma NEFA concentrations between our diabetic rats with and without arterial deposits may indicate a more severe diabetic state in the former group.

Many studies have shown premature arteriosclerosis in diabetics, especially in the muscular arteries of the leg $[32,33]$ and the coronary arteries $[34,35]$. Even though our findings involve only short-term effects of diabetes on arterial lipid metabolism, they support the findings of others that muscular arteries are more frequently involved than elastic arteries in diabetes.

Acknowledgements. This work was supported by Olavi Pykälistö Memorial Foundation and the Finnish Foundation for Cardiovascular Research. The authors are grateful to Professor Esko Nikkilä for his criticism of the manuscript, to Mrs. Sirkka Sutinen, M. Sc., for technical advice, and to Mrs. Anna-Liisa Marjalahti and Mrs. Raija Sirviö for their skilful technical assistance.

\section{References}

1. Clawson ET, Bell E (1949) The incidence of coronary disease in non-diabetic and diabetic persons. Arch Pathol Lab Med 48: 105-106

2. Garcia MJ, McNamara PM, Gordon T, Kannel WB (1974) Morbidity and mortality in diabetics in the Framingham population. Sixteen year follow-up study. Diabetes 23: 105-111

3. Reinilä A, Koivisto VA, Ákerblom HK (1977) Lipids in the pulmonary artery and the lungs of severely diabetic rats. A histochemical and chemical study. Diabetologia 13: 305-310

4. Reinilä A, Åkerblom HK, Koivisto VA (1979) The influence of insulin on the lipids in the pulmonary artery and the lungs of severely diabetic rats. A histochemical and chemical study. Diabetologia 16: 59-64

5. Rönning O, Isotupa K (1967) A method for intracardial injections on rats. Anat Rec 158: $245-248$

6. DHEW (1974) Manual of laboratory operations, lipid research clinics program. Lipid and lipoprotein analyses. DHEW Publ No (NIH) 75-628

7. Carrol JJ, Smith N, Babson AL (1970) A colorimetric serum glucose determination using hexokinase and glucose-6-phosphate dehydrogenase. Biochem Med 4: 171-180

8. Coburn HJ, Carrol JJ (1973) An improved manual and automated colorimetric serum glucose determination using hexokinase and glucose-6-phosphate dehydrogenase. Clin Chem 19: $127-130$

9. Dole VP (1956) A relationship between non-esterified fatty acids in plasma and the metabolism of glucose. $J$ Clin Invest 35: $150-154$

10. Eggstein H, KreutzFH (1966) Eine neue Bestimmung der Neutralfette im Blutserum und Gewebe. Klin Wochenschr 44: 262-267

11. Wybenga DR, Pileggi VJ, Distine PH, Di Giorgio J (1970) Direct manual determination of serum total cholesterol with a single stable reagent. Clin Chem 16: 980-984

12. Weibel ER (1973) Stereological techniques for electron microscopic morphometry. In: Hayat MA (ed) Principles and techniques of electron microscopy, vol 3. Van Nostrand Reinhold Company, New York Cincinnati Toronto London Melbourne, p 237-296

13. Blanchette-Mackie EJ, Scow RO (1971) Sites of lipoprotein lipase activity in adipose tissue perfused with chylomicrons. Electron microscope cytochemical study. J Cell Biol 51: 1-25

14. Reynolds ES (1963) The use of lead citrate at high $\mathrm{pH}$ as an electron opaque stain in electron microscopy. J Cell Biol 17: 208-212

15. Lentz TL (1971) Cell fine structure. Saunders, Philadelphia London Toronto, p 83-102

Fig. 1. Muscular pulmonary artery section from a diabetic rat showing lipid containing vacuoles (Lv) in a medial smooth muscle cell (SM). The vacuoles are closely associated with mitochondria $(\mathrm{MT}) . \times 67000$

Fig. 2. Coronary artery section from a diabetic rat showing accumulation of lipid (Lv) in a medial smooth muscle cell. The vacuoles (Lv) are associated with the endoplasmic reticulum (ER), Golgi apparatus (G) and mitochondria (MT). $\times 40000$

Fig. 3. Muscular pulmonary artery from a diabetic rat with a very high plasma NEFA concentration (2.4 mmol/l), showing massive accumulation of lipid in a medial smooth muscle cell (SM). The lipid droplets (L) are spread throughout the cell. $E=$ endothelium, IE $=$ internal elastic lamina, $\mathrm{LM}=$ lumen, $\mathrm{V}=$ vesicles in the endothelium. $\times 15000$

Fig. 4. Histochemical reactions in a muscular pulmonary artery from a diabetic rat demonstrating the presence of triacylglycerol deposits, seen as dark spots (arrows), throughout the media (M). The intima (I) does not contain lipid deposits. $L M=$ lumen, $N=$ nucleus. The tissue specimen was incubated with pancreatic lipase and then treated with $\mathrm{Pb}^{++}$and $\mathrm{S}^{--}[16] . \times 650$ 
16. Adams CWM, Abdulla YH, Bayliss OB, Weller OR (1966) Histochemical detection of triglyceride esters with specific lipase and calcium lead sulphide technique. J Histochem Cytochem 14: 385-395

17. Weber AF, Philips MG, Bell JT (1956) An improved method for the Schultz cholesterol test. J Histochem 4: 308-309

18. Adams CWM (1965) Osmium tetroxide- $\alpha$-naphthylamine (OTAN) method for phospholipids, cholesterol esters and triglyceride esters. In: Adams CWM (ed) Neurohistochemistry. Elsevier, Amsterdam, p 55-56

19. Campbell PN, von der Decken A (1974) Cytomembranes and ribosomes. In: Beck F, Lloyd JB (eds) The cell in medical science, vol 1: The cell and its organelles. Academic Press, London, p 143-181

20. Spector AA (1971) Metabolism of free fatty acids. Prog Biochem Pharmacol 6: 130-176

21. Baum H (1974) Mitochondria and peroxisomes. In: Beck F, Lloyd JB (eds) The cell in medical science, vol 1: The cell and its organelles. Academic Press, London, p 183-272

22. Bierman EL, Dole VP, Roberts T (1957) An abnormality of non-esterified fatty acid metabolism in diabetes mellitus. Diabetes 6: 475-479

23. Scow RO, Chernick SS (1970) Mobilization, transport and utilization of free fatty acids. In: Florkin M, StotzE (eds) Comprehensive biochemistry, vol 18: Lipid metabolism. Elscvier, Amsterdam, p 19-49

24. Nikkilä EA (1971) Transport of free fatty acids. Prog Biochem Pharmacol 6: 102-129

25. Spector AA (1975) Fatty acid binding to plasma albumin. J Lipid Res 16: 165-179

26. Scow RO, Olivecrona T (1977) Effect of albumin on products formed from chylomicron triacylglycerol by lipoprotein lipase in vitro. Biochim Biophys Acta 487: 472-486

27. Kovacev VP, Scow RO (1966) Effects of hormones on fatty acid release by rat adipose tissue in vivo. Am J Physiol 210: 1199-1208
28. Spector AA (1978) Transport of fatty acid in the circulation In: Dietschy JM, Gotto Jr AM, Ontko JA (eds) Disturbanes in lipid and lipoprotein metabolism. Am Physiol Soc, Washington, p 229-249

29. Heimberg M, Goh EH, Klausner HA, Soler-Argilaga C, Weinstein S, Wilcox HG (1978) Regulation of hepatic metabolism of free fatty acids: Interrelationships among secretion of very low density lipoproteins, ketogenesis, and cholesterogenesis. In: Dietschy JM, Gotto Jr AM, Ontko JA (eds) Disturbances in lipid and lipoprotein metabolism. Am Physiol Soc, Washington, p 251-267

30. Altman PL, Dittmer DS (1961) Blood and other body fluids. Fed Am Soc Exp Biol, Washington, p 5-47

31. Nikkilä EA (1973) Triglyceride metabolism in diabetes mellitus. Prog Biochem Pharmacol 8: 271-299

32. Ferrier TM (1964) Radiologically demonstrable arterial calcification in diabetes mellitus. Aust NZ J Med 13: 222-228

33. Neubauer B (1978) Diabetic macroangiopathy. An angiographic study of the lower extremity. Diabetologia 15: 257

34. Liebow IM, Hellerstein HK, Miller M (1955) Arteriosclerotic heart disease in diabetes mellitus. Am. J Med 18: 438-447

35. Goldenberg S, Alex M, Blumenthal HT (1958) Sequalae of arteriosclerosis of the aorta and coronary arteries. Diabetes 7 : 98-108

Received: January 8,1980 ,

and in revised form: July 2, 1980

A. Reinilä, M. D.

Department of Pathology

University of Oulu

Kajaanintie 52D

SF-90220 Oulu 22

Finland 